\title{
FERTILIZER ADDITION INDUCES A CASCADE OF PLANT COMMUNITY RESPONSES IN A MEADOW
}

\author{
BAI, Y. ${ }^{1,2,3}-$ XIA, J. ${ }^{1}-$ SCHELlENBERG, M. P. ${ }^{3}-$ YAN, R. ${ }^{4}-$ ZHANG, R. ${ }^{5}-$ LV, S. ${ }^{2}-$ WeI, Z.$^{2 *}$ \\ ${ }^{1}$ Shandong Key Laboratory of Eco-Environmental Science for Yellow River Delta, Binzhou \\ University, Binzhou 256603, China \\ ${ }^{2}$ College of Grassland, Resources and Environment/Key Laboratory of Grassland Resources of \\ the Ministry of Education/Inner Mongolia Key Laboratory of Grassland Management and \\ Utilization/Key Laboratory of Forage Cultivation, Processing and High Efficient Utilization of \\ the Ministry of Agriculture, Inner Mongolia Agricultural University, No. 29 Erdos Street, \\ Hohhot 010011, Inner Mongolia, China
}

${ }^{3}$ Swift Current Research and Development Centre, Agriculture and Agri-Food Canada, 1 Airport Rd, Box 1030, Swift Current, Saskatchewan S9H 3X2, Canada

${ }^{4}$ Institute of Agricultural Resources and Regional Planning, Chinese Academy of Agricultural Sciences, Beijing 100081, China

${ }^{5}$ Key Laboratory of Ecosystem Network Observation and Modeling, Institute of Geographic Sciences and Natural Resources Research, CAS, Beijing 100101, China

*Corresponding author

e-mail: nmndwzj@163.com

(Received $13^{\text {th }}$ Apr 2021; accepted $19^{\text {th }}$ Jul 2021)

\begin{abstract}
Fertilizer addition can improve soil nutrients in degraded grasslands, change plant community composition, and promote community productivity. An experiment was established in 2014 near Hulunbuir Grassland Ecosystem National Field Observation Station at Hulunbuir in Inner Mongolia, China, using L14 $\left(3^{4}\right)$ orthogonal test with 14 treatments totally, to compare the change of plant community productivity and plant diversity during three years of fertilization. We monitored the dynamic responses of aboveground biomass, plant species composition, species richness, Shannon diversity, Pielou's evenness after nitrogen $(\mathrm{N})$, phosphorus $(\mathrm{P})$, and potassium $(\mathrm{K})$ addition once a year from 2014 to 2016. Compared to the control treatment of no additional fertilizer, we found that, (1) The fertilization combination of $\mathrm{N}\left(274 \mathrm{~kg} \mathrm{ha}^{-1}\right), \mathrm{P}\left(350 \mathrm{~kg} \mathrm{ha}^{-1}\right)$, and $\mathrm{K}\left(57 \mathrm{~kg} \mathrm{ha}^{-1}\right)$ had a greater effect on biomass after the third year of fertilizer addition; (2) Gramineae accounted for a major portion of biomass in 2016, whereas the proportion of other species declined or disappeared; and (3) the longer the fertilization treatments went on, the lower Shannon diversity and Pielou's evenness turned out to be. All these responses are strongly interrelated in a cascade of changes. The interrelationships between fertilizers and different plant communities attribute the change not only to climate shift but also to time.
\end{abstract}

Keywords: nitrogen fertilizer, phosphorus fertilizer, potassium fertilizer, community biomass, species diversity

\section{Introduction}

Arid and semi-arid lands cover nearly one-third of the terrestrial land surface and may be highly sensitive to anthropogenic nutrient inputs (Zhou et al., 2018). Nitrogen $(\mathrm{N})$, phosphorus $(\mathrm{P})$, and potassium $(\mathrm{K})$ are macro nutrient elements constraining plant productivity in many grassland ecosystems. In recent decades, due to the high intensity of human activities, including the expansion of agriculture and fertilizer application, the content of $\mathrm{N}$ in the soil is changing on varying degrees (Yahdjian et al., 2011). $\mathrm{N}$ is 
considered to be the second most limiting factor for plant growth in arid lands globally after water. Unlike most other nutrients, which generally are derived from the breakdown of rocks, nitrogen is derived from the atmosphere. Plants that form symbioses with nitrogen-fixing bacteria, which can acquire nitrogen from its vast atmospheric reservoir, are widespread in natural grasslands and well-managed pastures. The effects of $\mathrm{N}$ addition are altering plant community structure including plant productivity and biomass allocation (Gough et al., 2000; Plassmann et al., 2009; Han et al., 2011). Additionally, the nutrients such as phosphorus, potassium, and micronutrients constrain the activity of biological nitrogen fixers (Vitousek, 2015). Simultaneously, nitrogen-phosphorus co-limitation could reflect a nitrogen-induced increased in the production of nitrogen-rich phosphatase enzymes that render phosphorus more available (Pegtel et al., 1996; Houlton et al., 2008; Bai et al., 2017). The principle of grassland fertilization is not only based on the nutritional needs of the plant and the ability of providing nutrients for the soil, but should be also considered the effects and benefits of fertilization. Due to the diverse types of grassland soils in different regions, various types and concentrations of fertilizer will impact changes in grassland productivity differently. Therefore, the definition of fertilizer concentration levels are relative and there are no limits (Bai et al., 2010). Many studies focus on the effect of fertilization on biomass or nutrients of artificial grassland, but only few studies focus on the effect of biomass and species composition in natural grasslands (Blaxter et al., 2009; Xu et al., 2015). Both organic manure and chemical fertilizer applied on the soil of natural grassland can significantly increase grasses growth, but there is a difference in their effects on species composition (Eek et al., 2001; Jiang et al., 2013). A long-term location fertilization study in China indicated that a single application of nitrogen fertilizer on grassland could promote the development of grass, but was not favourable to the growth of legumes. Compared to nitrogen fertilizer, phosphorus fertilizer was more beneficial to the growth of legumes, and potassium fertilizer could promote the photosynthesis of plants and improve cold resistance and disease resistance of plants. Therefore, the balanced application of $\mathrm{N}, \mathrm{P}, \mathrm{K}$ fertilizer has positive effects on grassland yield and quality (Nie et al., 2012). Plant diversity plays an important role for grassland ecosystem functions and is a key for controlling productivity with changing climate (Hector et al., 1999; Zhang et al., 2018). When the diversity of plants is reduced, the buffering effect of the grassland will be reduced and therefore, the service function of the ecosystem is threatened. As a result, ecologists are continually concerned of the relationship between fertilization and plant diversity (Huberty et al., 1998; Richardson et al., 1999; Zeng et al., 2009). There may be positive, negative, or no significant correlations between fertilization and species richness, but thus far no definitive conclusion has been determined (Rajaniemi, 2002; Hejcman et al., 2007; Hautier et al., 2014; Leimer et al., 2015).

The Hulunbuir Meadow steppe is located in Northeast China. It is one of three world-famous grasslands, with an area of $1.08 \times 10^{4} \mathrm{~km}^{2}$. The grassland ecosystem provides fodder for livestock by grazing or mowing. The plant productivity depends on climatic conditions such as temperature and precipitation. The decomposition rate of soil organic matter slowly is constrained mainly by low temperature, which leads to trapping of the nutrient in forms unavailable to the plant. One of the macro-nutrients $\mathrm{N}$, $\mathrm{P}$, and $\mathrm{K}$ is add to the soil in short-term, it could generally increase primary productivity and soil organic matter, but excessive fertilization may result in an imbalance of soil and plant nutrients, soil acidification, and toxic effects to plants. This leads to 
uncertainty in the overall outcome for plant communities (Warman and Cooper, 2000; Pan et al., 2014). Therefore, the appropriate types and concentrations of fertilizers are the key factor for grassland improvement. Most studies on fertilizer for grassland pay more attention to comparing one or two types at different levels (Oomes, 1990). In order to analyze the effects of different fertilization regimes on the development of natural grassland ecosystems, we tested biomass, plant species composition, and plant diversity under various fertilizer treatments in the Hulunber Leymus chinensis Meadow steppe over a three years' period. This study was designed to address the following three questions: (i) How does short-term N, P, K fertilizer addition affect aboveground net primary productivity? (ii) Which is optimal option of fertilizer combination for improvement of grassland yield? (iii) How does species diversity change with optimal fertilization levels in different years?

\section{Materials and methods}

\section{Study sites and experimental design}

The fertilization experiment was conducted near Hulunbuir Grassland Ecosystem National Field Observation Station, China (49.2313N, 120.0247E). The station, which was built in 1997 by the Chinese Academy of Agricultural Sciences, is located in the core area of Hulunbuir Meadow steppe. The average altitude of this area is 650 m.a.s.l. The climate is continental semi-arid with a dry and cold winter and a rainy summer. The mean annual temperature is $0{ }^{\circ} \mathrm{C}$. The annual precipitation is about $250-350 \mathrm{~mm}$, of which about half falls between June and August. The frost-free period is 85 to 155 days. The type of soil is chestnut soil. The vegetation is dominated by Leymus chinensis (Trin.) Tzvel., Vicia amoena (Fisch.ex DC.), Thalictrum squarrosum (Steph.), Pulsatilla turczaninovii (Kryl. et Serg.), Stipa baicalensis (Roshev.), and Cleistogenessquarrosa (Trin.) Keng, and accompanied by Carexduriuscula (C. A. Mey.), Allium bidentatum (Allium L.), and Artemisia tanacetifolia (Linn.). Prior to 2014, the grassland was irregularly grazed by cattle and the site was mowed once a year in autumn.

In order to prevent grazing, the fertilization experiment was started at a permanent area within an enclosure in 2013, whereas the mowing regime also occurred within the enclosure. The plots had similar plant community composition and structure before fertilizing. Fourteen $6 \times 10 \mathrm{~m}$ plots were randomly placed with an average separation distance of about $2 \mathrm{~m}$ in May 2014. An L14 $\left(3^{4}\right)$ orthogonal test was chosen to test their effects on plant community biomass, plant species composition, species richness, Shannon diversity, and Pielou's evenness. The orthogonal test is an efficient measurement to assay the comprehensive effect of multiple factors, finding the dominant factors and the best combination of levels for them with the least experimental trials, enhancing the reproducibility of the experimental results (Montgomery, 1991). The L14 $\left(3^{4}\right)$ orthogonal test for the experiment was to reduce workload, while it could arrange fourteen treatments with three factors and their four levels each, and test the interactions between factors if they exist. The local soil nutrient survey results in 2013, the total $\mathrm{N}$ content in $0-30 \mathrm{~cm}$ soil was $2.86 \mathrm{~g} \cdot \mathrm{kg}^{-1}$, the total $\mathrm{P}$ was $0.49 \mathrm{~g} \cdot \mathrm{kg}^{-1}$ and the total $\mathrm{K}$ was $22.96 \mathrm{~g} \cdot \mathrm{kg}^{-1}$. Comprehensive consideration the soil survey result and local traditional fertilization, selecting fourteen plots (T1 to T14) with nitrogen fertilizer $(\mathrm{N})$, phosphate fertilizer $(\mathrm{P})$, and potassium fertilizer $(\mathrm{K})$, and four fertilization concentration levels for each fertilizer (Table 1). The concentrations of four $\mathrm{N}$ treatments were 0,91 , 183 and $274 \mathrm{~kg} \mathrm{ha}^{-1}$ (hereafter denoted as N1, N2, N3 and N4, respectively), four P 
treatments were $0,175,350,525 \mathrm{~kg} \mathrm{ha}^{-1}$ (hereafter denoted as P1, P2, P3, and P4, respectively), and four $\mathrm{K}$ treatments were $0,28,57,85 \mathrm{~kg} \mathrm{ha}^{-1}$ (hereafter denoted as $\mathrm{K} 1$, $\mathrm{K} 2, \mathrm{~K} 3$, and $\mathrm{K} 4$, respectively), three replicates for each of the fourteen plots (hereafter denoted as T1-T14, respectively). The fertilizer was broadcast on the surface by hand once a year, and the date of fertilization was in early June every year.

Table 1. L14 $\left(3^{4}\right)$ orthogonal test for the combinational effect trial and fertilization amounts of Nitrogen (N), Phosphorous (P), and Potassium (K) applied

\begin{tabular}{c|c|c|c|c}
\hline \multirow{2}{*}{ Plot number } & \multirow{2}{*}{ Treatment } & \multicolumn{3}{|c}{ Fertilization amounts of N, P, K } \\
\cline { 3 - 5 } & & $\begin{array}{c}\mathbf{C O N}_{2} \mathbf{H}_{\mathbf{4}} \\
\left(\mathbf{k g ~ h a}^{-1}\right)\end{array}$ & $\begin{array}{c}\mathbf{C a P}_{2} \mathbf{H}_{\mathbf{4}} \mathbf{O}_{\mathbf{8}} \\
\left(\mathbf{k g ~ h a}^{-1}\right)\end{array}$ & $\begin{array}{c}\mathbf{K}_{2} \mathbf{S O}_{\mathbf{4}} \\
\left(\mathbf{k g ~ h a}^{-1}\right)\end{array}$ \\
\hline T1 & N0P0K0 & 0 & 0 & 0 \\
T2 & N0P2K2 & 0 & 350 & 57 \\
T3 & N1P2K2 & 91 & 350 & 57 \\
T4 & N2P0K2 & 183 & 0 & 57 \\
T5 & N2P1K2 & 183 & 175 & 57 \\
T6 & N2P2K2 & 183 & 350 & 57 \\
T7 & N2P3K2 & 183 & 525 & 57 \\
T8 & N2P2K0 & 183 & 350 & 0 \\
T9 & N2P2K1 & 183 & 350 & 28 \\
T10 & N2P2K3 & 183 & 350 & 85 \\
T11 & N3P2K2 & 274 & 350 & 57 \\
T12 & N1P1K2 & 91 & 175 & 57 \\
T13 & N1P2K1 & 91 & 350 & 28 \\
T14 & N2P1K1 & 183 & 175 & 28 \\
\hline
\end{tabular}

The urea $(\mathrm{N} \geq 46.4 \%)$, calcium superphosphate $\left(\mathrm{P}_{2} \mathrm{O}_{5} \geq 16 \%\right)$, potassium sulfate $\left(\mathrm{K}_{2} \mathrm{O} \geq 51 \%\right)$ were applied for nitrogen fertilizer $(\mathrm{N})$, phosphate fertilizer $(\mathrm{P})$, and potassium fertilizer $(\mathrm{K})$ respectively with artificial fertilization

\section{Biomass sampling}

Except for surface litter, the total biomass of all plants was harvested from $0.5 \times 0.5 \mathrm{~m}$ quadrats in August of each year between 2014 and 2016 with three repetitions randomly selected in each plot (Fig. 1). Different species were separately cut to the ground level using scissors in each square area. All species were separately weighed after drying at $65^{\circ} \mathrm{C}$ for $24 \mathrm{~h}$ in the oven. The plant community biomass was the total amount of all plants biomass in each plot (Sala et al., 1988).

\section{Plant species composition and plant diversity}

In each plot, we randomly selected three $0.5 \times 0.5 \mathrm{~m}$ quadrats for the investigation of plant species composition and plant diversity. Every August was chosen to test because of the peak number of plant species biomass at this time. Plant species composition was calculated using the percentage of the species weight in the community. The richness was defined as the number of species per square area. The diversity index was calculated using the Shannon-Wiener diversity index (Shannon, 1949). Evenness of species was calculated using Pielou's evenness index (Pielou, 1966). During the three years, 62 plant species were identified within the study area, and divided into 6 plant 
functional groups, including 9 Poaceae, 8 Fabaceae, 4 Ranunculaceae, 1 Cyperaceae, 11 Asteraceae, and 29 miscellaneous species or forbs (Table 2). We have selected cumulative important values IV $\geq 5$ to be classified as, Poaceae, Fabaceae, Ranunculaceae, Cyperaceae, Asteraceae; other important values (IV) $<5$ were classified as miscellaneous species or forbs. The cumulative important values (IV) of different populations were calculated and classified according to the morphology of the different plants (Bu and Jiang, 2014).

The cumulative important values (IV):

$$
I V=\frac{R D+R H+R M}{3}
$$

where: $\mathrm{RD}=$ relative density, $\mathrm{RH}=$ relative height, $\mathrm{RM}=$ relative dry mass.
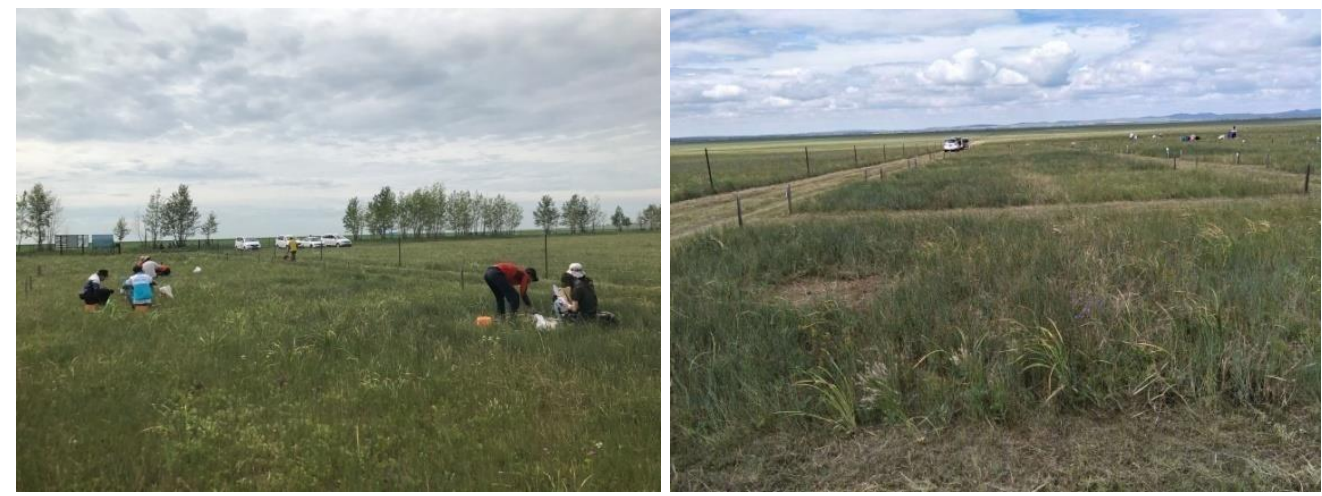

Figure 1. The photo of experiment site and taking sample

Table 2. Classification of functional group

\begin{tabular}{c|c}
\hline Plant functional groups & Plant species \\
\hline Gramineae & Leymus chinensis \\
& Stipa baicalensis \\
& Achnatherum sibiricum \\
& Calamagrostis epigeios \\
& Poa pratensis \\
& Koeleria cristata \\
& Cleistogenes squarrosa \\
& Bromus inermis \\
& Festuca ovina \\
\hline Leguminosae & Astragalus adsurgens \\
& Vicia amoena \\
& Thermopsis lanceolata \\
& Astragalus melilotoides \\
& Astragalus hinbaticus \\
& Oxytropis myriophylla \\
& Melissitus ruthenica \\
& Melilotus dentate \\
\hline
\end{tabular}




\begin{tabular}{|c|c|}
\hline Ranunculaceae & $\begin{array}{c}\text { Pulsatilla turczaninovii } \\
\text { Thalictrum squarrosum } \\
\text { Clematis hexapetala } \\
\text { Caltha palustris }\end{array}$ \\
\hline Cyperaceae & Carex duriuscula \\
\hline Asteraceae & $\begin{array}{c}\text { Artemisia dacunculus } \\
\text { Artemisia tanacetifolia } \\
\text { Scorzonera austriaca } \\
\text { Serratula centauroides } \\
\text { Heteropappus altaicus } \\
\text { Artemisia annua } \\
\text { Tanacetum parthenium } \\
\text { Tripolium vulgare } \\
\text { Lxerisson chifolia } \\
\text { Artemisia frigida } \\
\text { Saussurea amara }\end{array}$ \\
\hline Miscellaneous species or forbs & $\begin{array}{c}\text { Allium bidentatum } \\
\text { Allium tenuissimum } \\
\text { Lilium pumilum } \\
\text { Veratrum nigrum } \\
\text { Allium ledebourianum } \\
\text { Allium prostratum } \\
\text { Adenophora stenanthina } \\
\text { Adenophora paniculata } \\
\text { Viola verecumda } \\
\text { Chenopodium glaucum } \\
\text { Orobanche coerulescens } \\
\text { Swertia pseudochinensis } \\
\text { Gentianopsis barbata } \\
\text { Gentiana squarrosa } \\
\text { Galium verum } \\
\text { Saposhnikovia divaricata } \\
\text { Bupleurum chinense } \\
\text { Dontostemon dentatus } \\
\text { Lepidium apetalum } \\
\text { Dianthus chinensis } \\
\text { Linaria vulgaris } \\
\text { Veronica longirolia } \\
\text { Cymbariadahurica } \\
\text { Iris ventricosa } \\
\text { Potentilla acaulis } \\
\text { Potentilla verticillaris } \\
\text { Potentilla bifurca } \\
\text { Potentilla nudicaulis } \\
\text { Potentilla tanacetifolia } \\
\end{array}$ \\
\hline
\end{tabular}




\section{Statistical analysis}

We used one-way ANOVA to examine the main effects of fertilizer addition. Prior to analysis, we confirmed that our response variables met normality and equal variance assumptions. To test whether the impacts of fertilizer addition on community biomass, plant species composition, species richness, Shannon diversity, and Pielou's evenness differed across time, repeated analysis of variance (ANOVA) was performed with fertilizer addition as the between-subjects factors and years as the within-subject factor.

Based on the design and character of the orthogonal experiment, the effect of the nitrogen fertilizer gradient on biomass, species richness, Shannon diversity and Pielou's evenness were analyzed by using the same fertilizer gradient of phosphate fertilizer and potassium fertilizer. Nitrogen fertilizer was used as follows T1 (NOP0K0), T2 (NOP2K2), T3 (N1P2K2), T6 (N2P2K2), and T11 (N3P2K2); phosphate fertilizer was used as follows T1 (N0P0K0), T4 (N2P0K2), T5 (N2P1K2), T6 (N2P2K2), and T7 (N2P3K2); and potassium fertilizer was used as follows T1 (N0P0K0), T8 (N2P2K0), T9 (N2P2K1), T6 (N2P2K2), and T10 (N2P2K3). The average of no fertilizer (NOP0K0) and nitrogenfree fertilizer (NOP2K2) was used for the initial gradient of nitrogen fertilizer.

Data were subjected to analysis of variance (ANOVA) using SPSS 20.0 software (SPSS statistical package, Chicago, IL, United States). An alpha of 0.05 was used for statistical significance. If sources were significant, they then underwent an LSD test with significance again declared at the 0.05 level.

\section{Results}

\section{Environmental conditions during the fertilization experiment}

During the fertilization study, the average of growing-season monthly air temperature from May to August was similar in all three years, but there was a great difference in rainfall (Fig. 2). The average of growing-season rainfall in 2014 was $82.28 \mathrm{~mm}, 78 \%$ and $114 \%$ higher than that in 2015 and 2016 respectively. Especially in July, the rainfall in 2014 was four times more than that in 2015 and 2016, while June in 2014 was twice higher than that in 2015 and 2016 respectively.

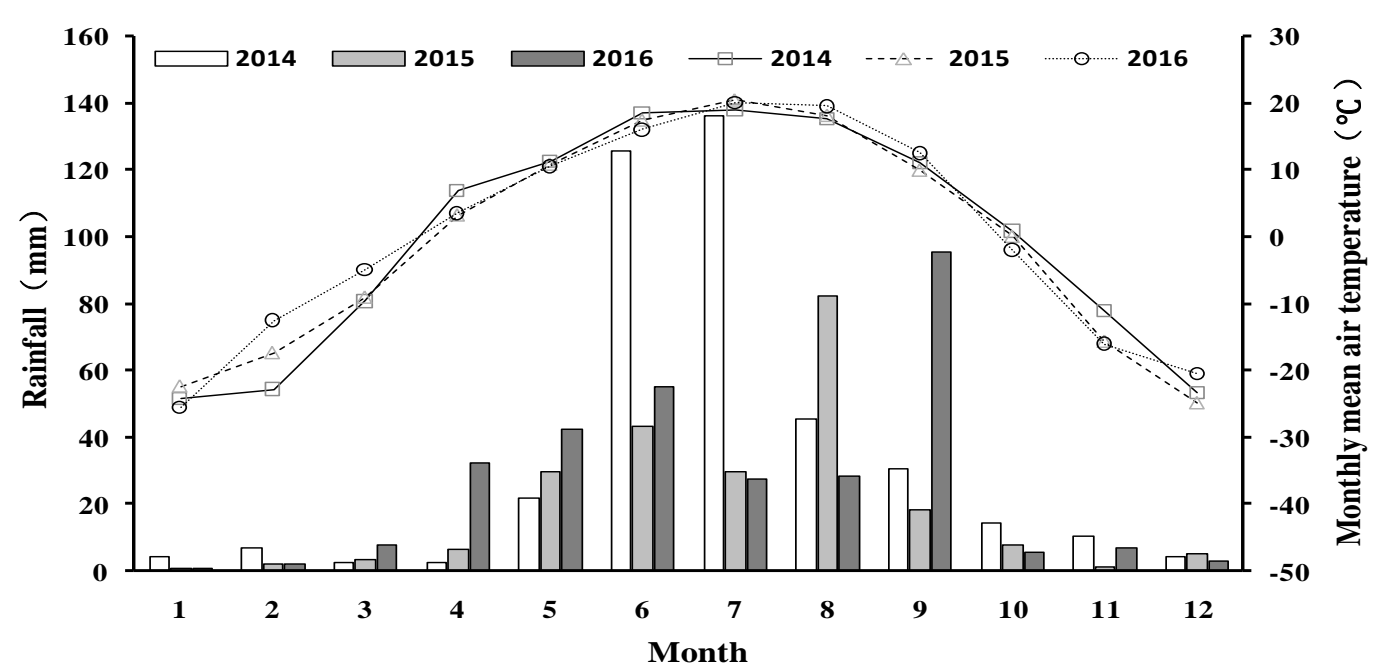

Figure 2. Monthly mean air temperature (lines) and rainfall (bars) received during the study period from 2014-2016 at the experiment site near Hulunbuir Grassland Ecosystem National Field Observation Station 


\section{Plant community biomass}

The effect of years and fertilizer treatments strongly influenced the total biomass of the community from 2014 to 2016 (Fig. 3). A positive effect of fertilizer on biomass emerged from T10 in 2014, was significantly higher than T1 (control), T4, T7, T8, and T9 $(P<0.05)$. This effect was short-lived. Except for T2, other treatments were significantly higher than $\mathrm{T} 1$ in $2015(P<0.05)$. Interestingly, a cumulative effect of the community biomass was more significant in 2016, which was the third year of fertilizer. T11 was the highest biomass in 2016 and higher than others except for T9 $(P<0.05)$. From the year difference analysis, the same treatment from 2014 to 2016 was significantly different in $\mathrm{T} 1, \mathrm{~T} 10, \mathrm{~T} 12$, and $\mathrm{T} 13$. There was no obvious difference between T10 and T11 in 2014 and 2015, but T11 was significantly higher than T10 in $2016(P<0.05)$. It indicated that T11 was the better fertilizer effect during the three years. The analysis shows that all fertilizer treatments performed better than the control (T1), so it could be concluded that fertilization plays a positive role in grassland productivity.

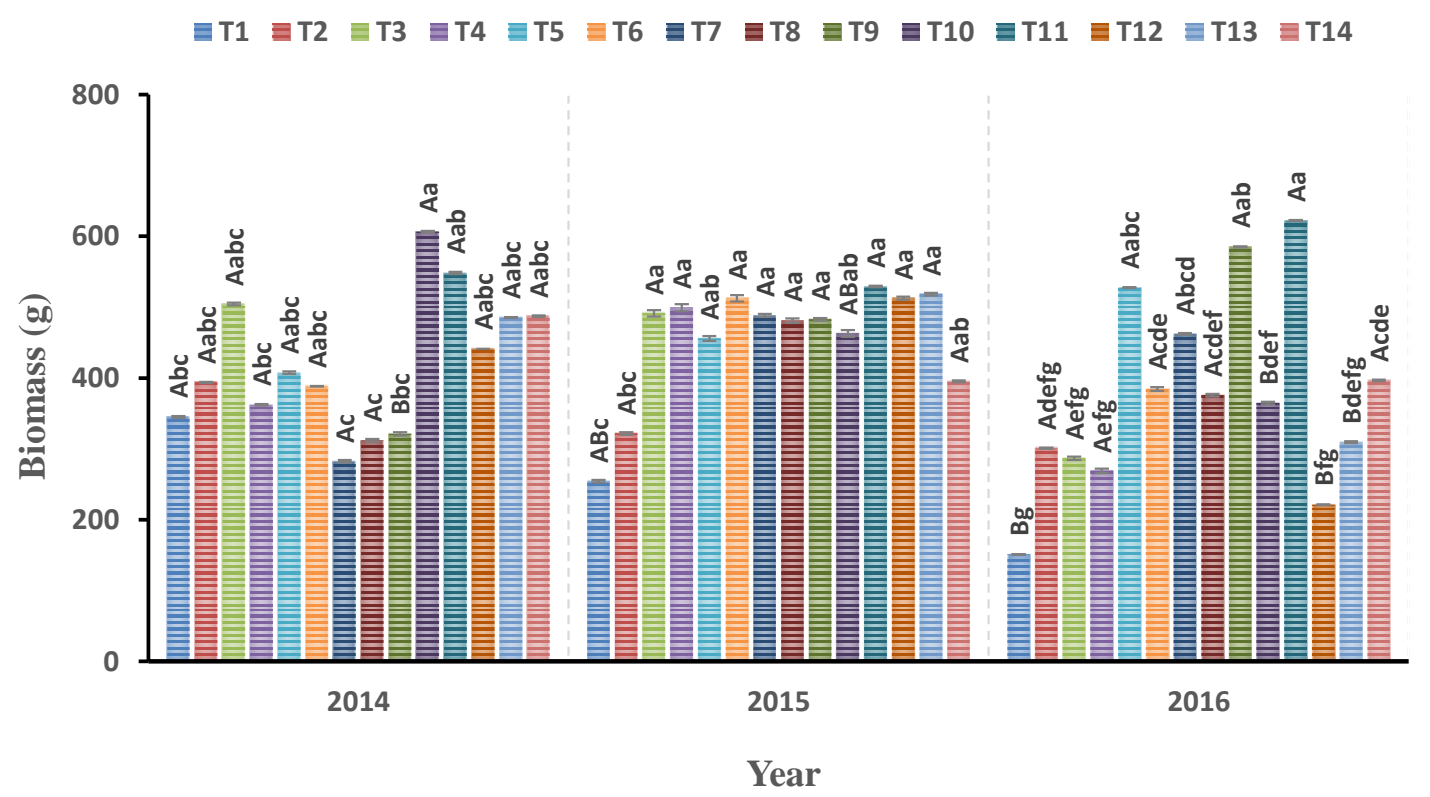

Figure 3. Effects of different fertilization treatments (Table 1) from 2014 to 2016 on total plant community biomass. The vertical bars represent the standard errors. Different upper-case letters indicate significant difference between years in the same treatment and lower-case letters indicate significant difference between treatments in the same year according LSD test at $P<0.05$

The mono-fertilizer effect was analyzed and the difference in partial treatments was significant (Fig. 4). In 2014, which was the first year of fertilization, there was only clear effect on $\mathrm{K}$ fertilizer at different levels. The community biomass increased with increasing the concentration of $\mathrm{K}$ when $\mathrm{N}$ and $\mathrm{P}$ fertilizer was the same fertilizer level. The trends of N, P, and K were similar in 2015. Except for N0 (P2K2), the biomass of all fertilizer treatments was significantly higher than the control (NOPOK0). Significant effects on biomass at the different level of N, P and K were also observed in 2016, which was the third year of fertilization. The biomass increased with $\mathrm{N}$ level increasing 
and N3 the highest one $(P<0.05)$. P1 (N2K2) was the highest one, P1 (N2K2) and P3 $(\mathrm{N} 2 \mathrm{~K} 2)$ were significantly higher than $\mathrm{P} 0(\mathrm{~N} 2 \mathrm{~K} 2)$ and the control $(P<0.05)$. The low $\mathrm{P}$ concentration met the needs of plant growth for phosphorus. This phenomenon is more obvious in terms of potassium fertilizer. Low $\mathrm{K}$ concentration was significantly higher than other levels of $\mathrm{K}(P<0.05)$.
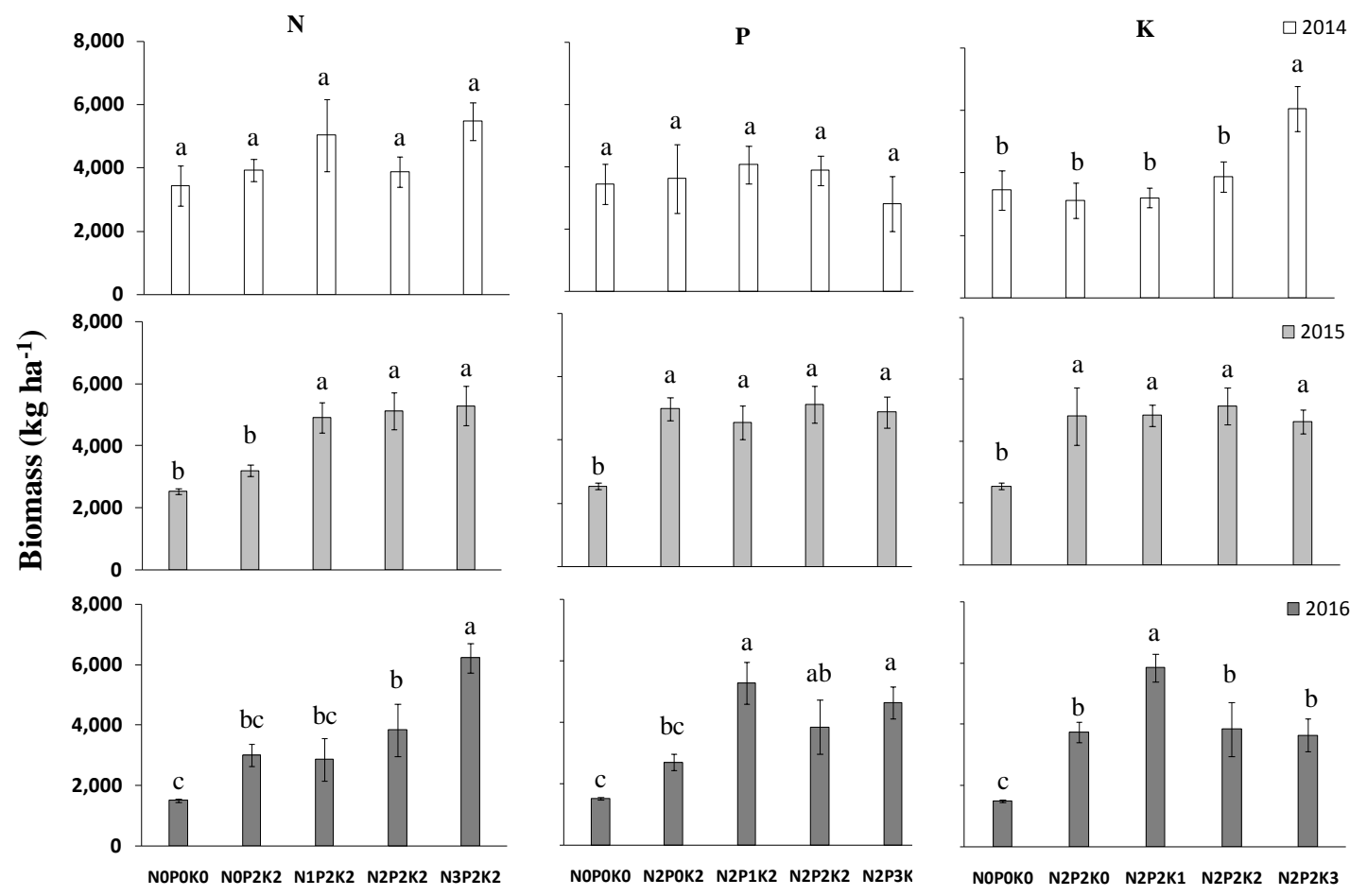

Fertilization level

Figure 4. Total community biomass for different $N, P, K$ levels at August fertilization in 2014, 2015, and 2016. NOPOKO represents no fertilizer, NO (P2K2), N1 (P2K2) and N3 (P2K2) represent that different concentration changes of nitrogen under the same phosphorus and potassium concentration. The same mean as phosphorus and potassium. The vertical bars represent the standard errors. Different letters indicate significant difference between treatments in the same year according LSD test at $P<0.05$. NS represents no significant differences

\section{Plant species composition}

The relative biomass of the functional groups in different treatments exhibited a significant effect on Gramineae for the three years (Table 3). In 2014, the Gramineae achieved the highest percentage of biomass (Fig. 5). In 2015, the dominance of miscellaneous species or forbs was gradually promoted, and Gramineae was replaced as the second proportion of biomass and the proportion of other species also decreased to varying degrees. In 2016, the Gramineae achieved the highest percentage again and the proportion of Cyperaceae increased in different treatments compared to 2015. The proportion of miscellaneous species or forbs declined significantly in 2016, Leguminosae and Ranunculaceae even disappeared in most treatments (Table 3). Except for Gramineae and Cyperaceae, some species in all treatments disappeared and the highest biomass of Gramineae was still T11. 


\section{4}

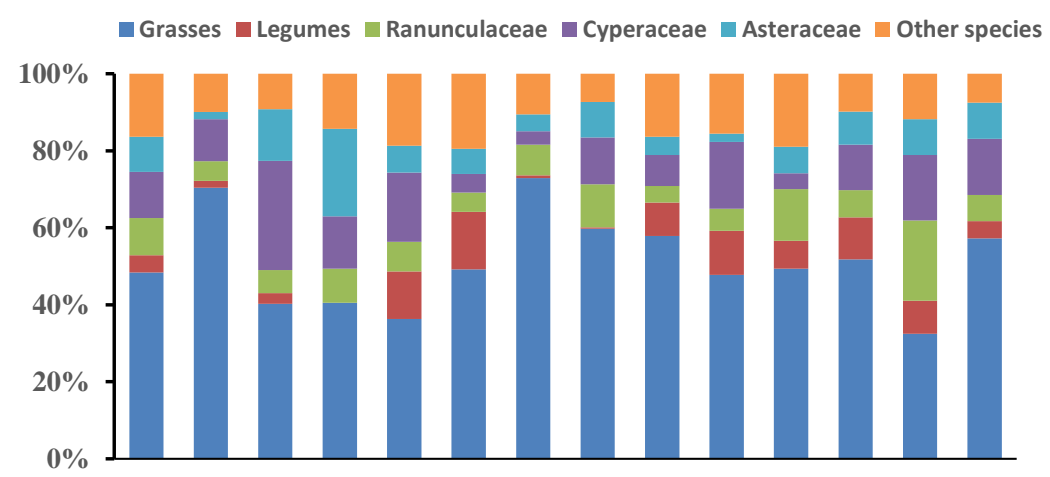

2015

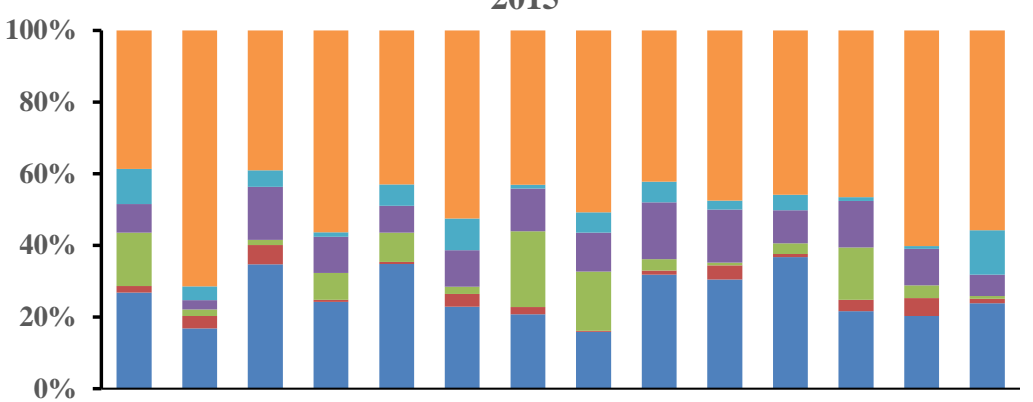

2016

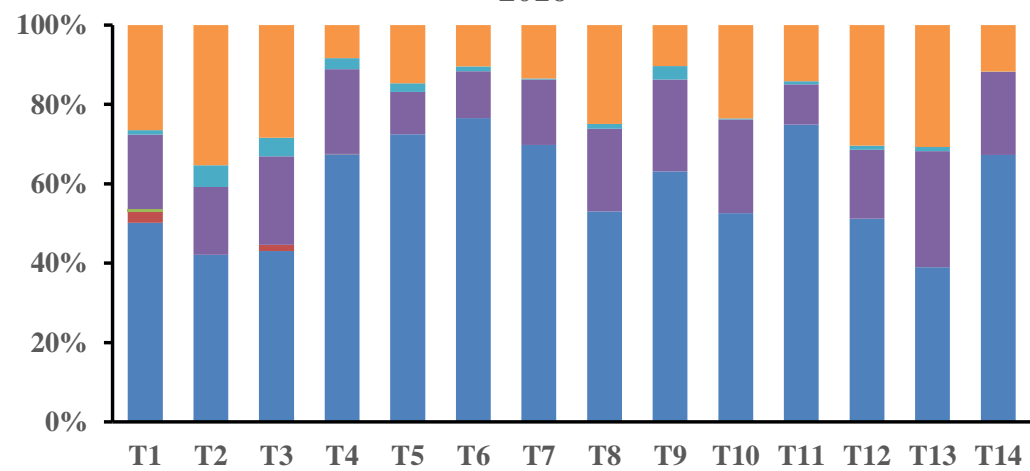

Treatment

Figure 5. Treatment (Table 1) effects on aboveground biomass of functional groups of plants in August for 2014, 2015 and 2016

Table 3. Results (P-value) of repeated measures ANOVA for biomass of the functional groups within fertilization treatments

\begin{tabular}{c|c|c|c|c|c|c}
\hline Biomass & Gramineae & Leguminosae & Ranunculaceae & Cyperaceae & Asteraceae & Miscellaneous species or forbs \\
\hline Treatment $(\mathrm{T})$ & $<0.001$ & 0.495 & 0.894 & 0.692 & 0.958 & 0.991 \\
Year $(\mathrm{Y})$ & $<0.001$ & $<0.001$ & $<0.001$ & 0.672 & $<0.001$ & 0.01 \\
$\mathrm{~T}^{*} \mathrm{Y}$ & 0.001 & 0.784 & 0.99 & 0.504 & 0.839 & 0.998 \\
\hline
\end{tabular}

\section{Species richness, Shannon diversity and Pielou's evenness of plant community}

Except for 2015, there were significant differences of species richness between 2014 and 2016, and T11 and T12 being the maximum in 2014 and 2016, respectively 
(Fig. 6A). It was also observed that T11 in 2014 was significantly higher than in 2015 and $2016(P<0.05)$. In 2015, T12 was significantly higher than the other two years (Fig. 6a). From the single fertilizer and year effect analysis, the significantly differences of N, P and $\mathrm{K}$ were observed (Fig. 7). In addition to the medium concentration of $\mathrm{N}$ (N2P2K2) and K (K2N2P2), other concentrations of N and K in 2014 were significantly higher than that in 2015 and $2016(P<0.05)$. The medium concentration of $\mathrm{N}, \mathrm{P}$, and $\mathrm{K}$ reached the maximum value in 2016. Similarly, a significant change in Shannon diversity during the three years was found $(P<0.05)$. The peak value of Shannon diversity was T13 in 2016 and no significant difference on T13 between 2014 and 2016 (Fig. 6B). The Shannon diversity of fourteen treatments in 2014 was no different or higher than that in 2015 and 2016 (Fig. 6b). This phenomenon was more obvious in the single fertilizer effect (Fig. 7). No matter which fertilizer and concentration, Shannon diversity for most treatments were higher in 2014 than that in 2015 and in 2016 $(P<0.05)$. From fertilizer concentration analysis, the control (NOP0K0) was always higher than other concentration of N, P and K during the three years. N0 (P2K2) was the lower one in 2014 and N2 (P2K2) became the lowest in 2016, while P3 (N2K2) in 2016 replaced P0 (N2K2) in 2014 to become the lowest $(P<0.05)$. For the concentration of $\mathrm{K}$, the high concentration (K3N2P2) was always lowest during the three years $(P<0.05)$. In 2015 and 2016, the significant differences of Pielou's evenness between treatments appeared. T9 in 2015 and 2016 were higher than partial treatments and no significant change between the two years (Fig. 6C). For the trend of year effect analysis, Pielou's evenness was similar to Shannon diversity (Fig. 6c). No matter which fertilizer and concentration, Pielou's evenness in 2014 were no differences or significantly higher than that in 2015 and $2016(P<0.05)$. There was no difference in Pielou's evenness in different $\mathrm{N}$ concentration in 2014 and 2015, but the difference appeared in 2016 and N1 was the lowest. Pielou's evenness in different P concentration was similar to N, and the lowest value was P1 in 2015 and 2016. The commonality of different $\mathrm{K}$ concentrations within the three years was that high concentration $(\mathrm{K} 3 \mathrm{~N} 2 \mathrm{P} 2)$ was always the lowest value $(P<0.05)$.

\section{Discussion}

\section{The plant community biomass response to fertilization}

The plant community biomass has an obvious change during the three years, as well as the less biomass of some treatments in 2016 than the other two years when severe changed in rainfall. It suggests that effects of fertilizer on plant community biomass are mediated, at least in part, by changes in rainfall (Yu et al., 2015). Many previous studies observed that these divergent effects of fertilizer addition are mediated by many factors which vary in time and space, including but not limited to fertilizer rate, the traits of the species composing the community and soil moisture and climate ( $\mathrm{Yu}$ et al., 2015; Brooks, 2003; Li et al., 2010). Although the biomass of some treatments in 2016 was lower, it could be seen that the difference in treatments in 2016 was more significant. T11 was the highest one in 2016 and it was still the best combination with the drought conditions between 2015 and 2016. Regardless of the amount of rainfall or scarcity between 2014 and 2016, the fertilizer effect continued to exists during these three years. The biomass of the fertilized plots was always higher than that of the non-fertilized one (T1). These could explain the addition of different concentrations of fertilizers applied that often led to different results in plant community biomass (Su et al., 2012; Zhou et 
al., 2018). Until 2016, our results also revealed that high concentration of nitrogen fertilizer (N3P2K2) was optimum based on the maximum biomass resulting from nitrogen fertilizer level, the low concentration of phosphorus (P1N2K2) and potassium (K1N2P2) were also optimum after the three years fertilization. These results do indicate that the growth of plants in the grassland with additional fertilizer would be greater which agrees with previous research results (Bai et al., 2010). However, there is a threshold of grassland productivity response to fertilization (Bai et al., 2010). As the amount or the period of fertilizer has increased, the amount of biomass did not increase or even decrease until it plateaued.

\section{Plant species composition response to fertilization}

Fertilizer addition has commonly been observed to change plant species composition and response of plant community members may dictate different responses to fertilizer addition (Gough et al., 2000; Hautier et al., 2014; Su et al., 2012). Nutrient limitation is a widespread phenomenon in grassland ecosystems. The responses of plant community to fertilizer addition are also contingent upon environmental conditions, especially moisture (Yu et al., 2015; Brooks, 2003; Su et al., 2012; Yahdjian et al., 2011; Zhou et al., 2018). With increasing levels of fertilizer addition, it benefits the dominance of alien annual plants and possibly promotes the invasion of new species in semi-arid regions, at the expense of natives (Brooks, 2003). In our study, the Gramineae became the dominant proportion again in 2016 and some species disappeared. This finding was consistent with previous studies (Zhou et al., 2018). This might suggest that the current dominants possess traits that allow them to benefit from, or showing effects after a period of time, while rare species do not. These responses are probably explained by a combination of differing $\mathrm{N}, \mathrm{P}$ and $\mathrm{K}$ acquisition strategies, fertilizer-use efficiency and maximum growth rates of these different functional types (Wamelink et al., 2009).

\section{Species richness, Shannon diversity and Pielou's evenness of plant community response to fertilization}

Diversity including species richness, Shannon diversity, Pielou's evenness and other dimensions commonly lead to enhanced productivity through the mechanism of complementarity (Hejcman et al., 2007; Yahdjian et al., 2011). Species losses and declines in species richness per unit area are commonly induced by fertilizer addition (Su et al., 2012; Clark et al., 2013). In our study, compared to the control, the richness of partial fertilizer treatments decreased significantly, but the highest value of richness appeared in T12 in 2016 (Fig. 6a). Regardless of N, P and K, the higher values were always in the fertilizer treatments in 2015 and 2016 (Fig. 7). However, there is a significant decline in the value of partial fertilization treatment compared to control. The reasons for the difference from other studies may be that $\mathrm{P}$ and $\mathrm{K}$ were applied together with $\mathrm{N}$ in this experiment but not as a sole treatment like in many other studies. Another reason was that our experiment was short-time and more time was required to fully demonstrate plant community effect. In contrast, the lowest value of Shannon diversity occurred in fertilized treatments, while the values with unfertilized treatment were always higher than some fertilized treatments. As the fertilizer year increased, the values of the same treatment in 2016 were all lower than that in 2014. This is a good illustration of the theory that the longer the fertilization treatments lasted, the lower Shannon diversity became. This phenomenon was also obvious in Pielou's evenness. 
These results do correspond with those obtained in several published studies and document a decreased in species diversity with fertilizer effect (Bobbink and Willems, 1993; Kahmen et al., 2002; Moog et al., 2002).
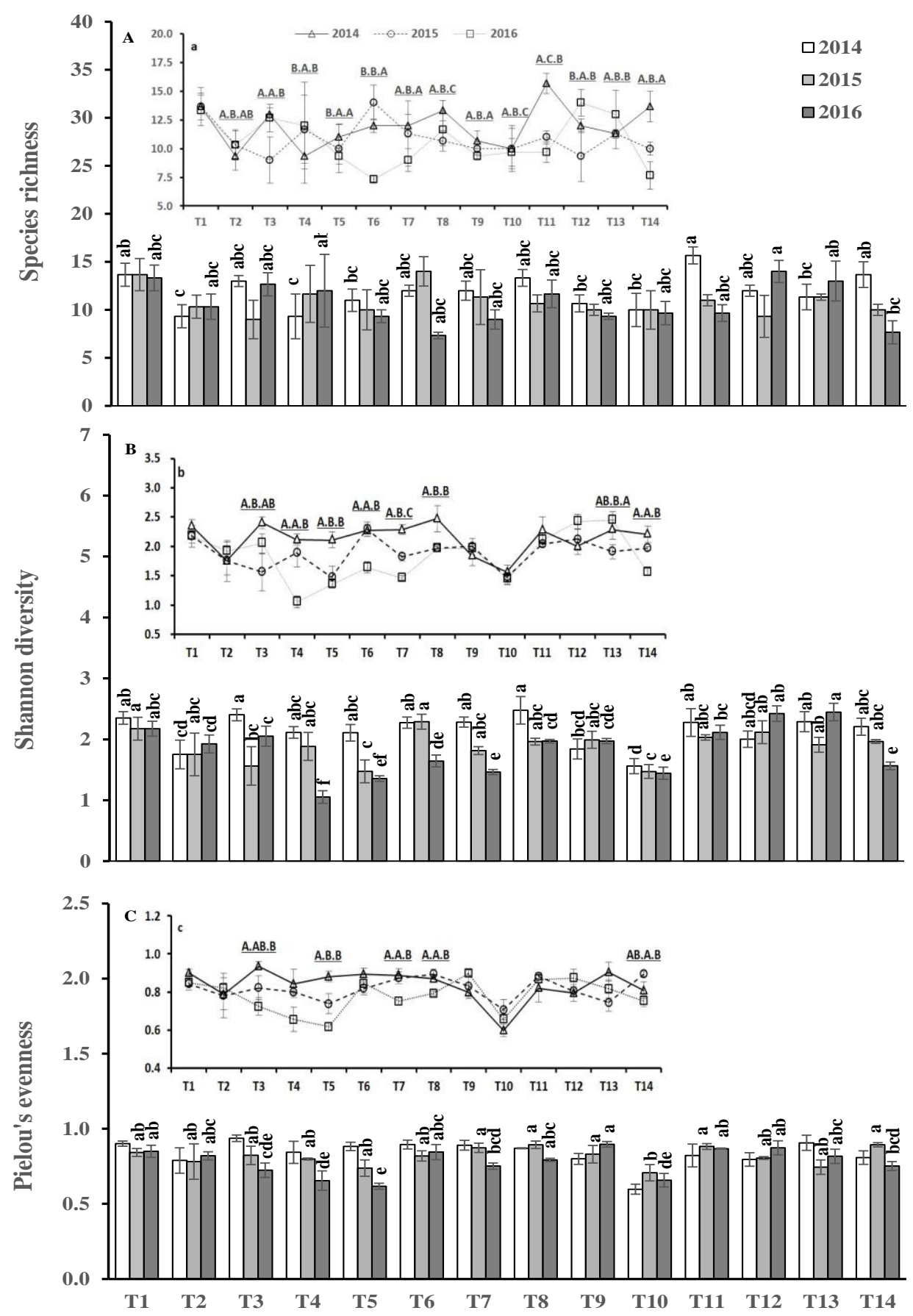

Treatment

Figure 6. Treatment (Table 1) and year (2014, 2015 and 2016) effects on species richness,

Shannon diversity and Pielou's evenness of plant community in August. Figure (A, B, C) represent treatment effects and different lower-case letters indicate significant difference in treatments (bars). Figure $(a, b, c)$ represent year effects and different upper-case letters indicate significant difference in years (lines) according LSD test at $P<0.05$. The vertical bars represent the standard errors 

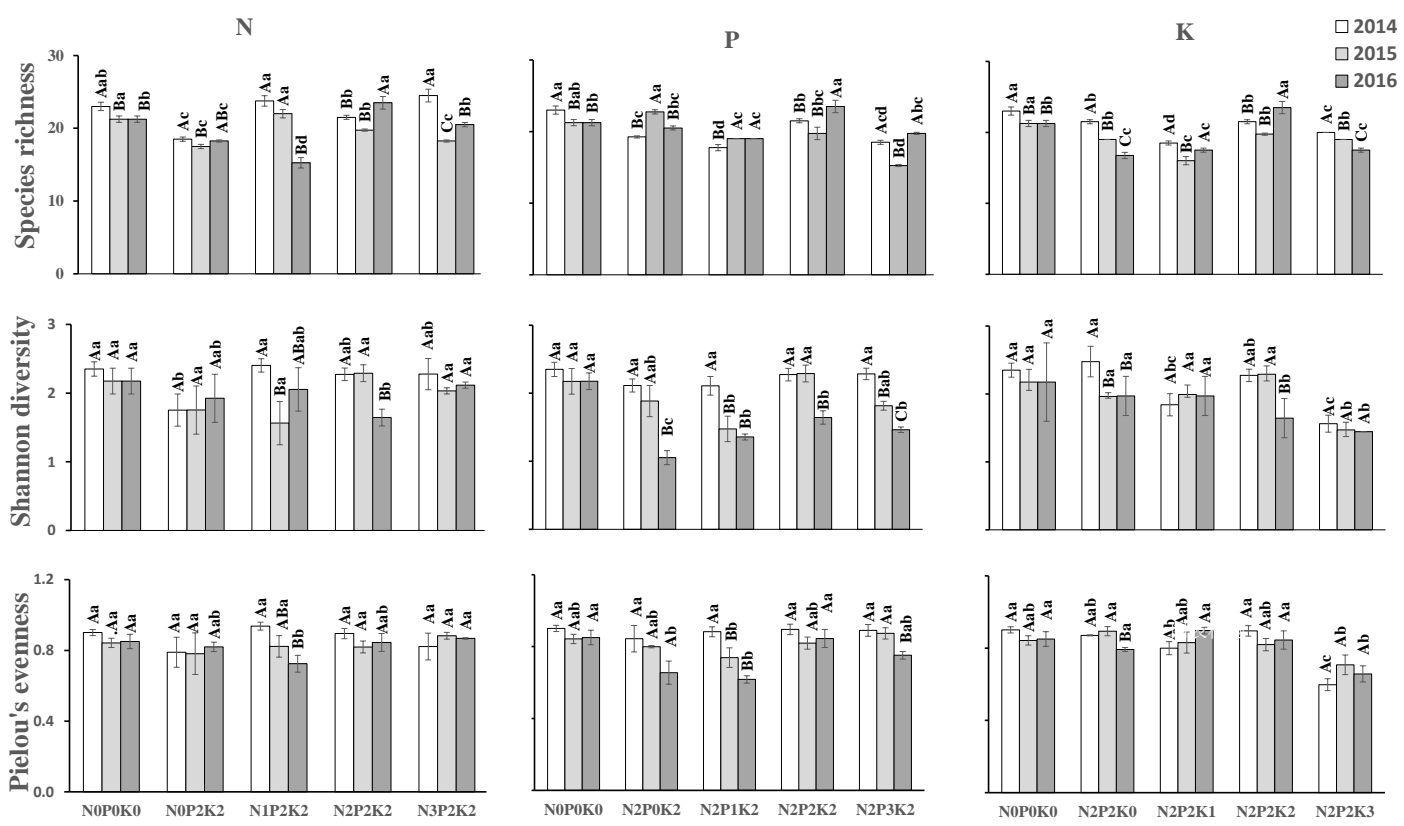

Fertilization level

Figure 7. Species richness, Shannon diversity and Pielou's evenness for four different fertilization levels by year of August fertilization (2014, 2015, and 2016). NOPOKO represents no fertilizer, NO $(P 2 K 2), N 1(P 2 K 2)$ and N3 (P2K2) represent that different concentration changes of nitrogen under the same phosphorus and potassium concentration. The same mean as phosphorus and potassium. The vertical bars represent the standard errors. Different letters indicate significant difference between treatments in the same year according LSD test at $P<0.05$

\section{Conclusion}

Based on the result, we recommend the combination of $\mathrm{N}\left(274 \mathrm{~kg} \mathrm{ha}^{-1}\right), \mathrm{P}\left(350 \mathrm{~kg} \mathrm{ha}^{-1}\right)$, and $\mathrm{K}\left(57 \mathrm{~kg} \mathrm{ha}^{-1}\right)$, and annually to maximize plant community productivity from the semi-arid grassland in Hulunbuir Inner Mongolia, China. Gramineae accounted for the major proportion of biomass in the third year of fertilization, whereas the proportion of other species declined or disappeared. The longer the fertilization treatments went on, the lower Shannon diversity and Pielou's evenness turned out to be. All these responses are strongly interrelated in a cascade of changes. We further establish that effects on plant community biomass are additively influenced by the dose of fertilizer applied and duration of application. In our study, the effects of the year were consequently significant on many indicators. It could indicate that some other factor could have influence on the plant community indicators. Therefore, we conclude that water control will be carried out the original design, to simulate the impact of different precipitation on the experimental results of this study in the future.

Acknowledgements. The authors gratefully acknowledge the technical support of the staff of the Hulunbuir Grassland Ecosystem National Field Observation Station. Special thanks go to Jingzhong Dai and Jing Yao for support during the data collection and regular management of the experimental plots. The authors also thank Shijie Lv (Inner Mongolia Agricultural University) for valuable input to the manuscript. This work was supported by China National Public Welfare Industry (Agriculture) Research Project [grant number 2013060] and China National Key Research and Development Program Project [grant number 2016YFC0500603]. 


\section{REFERENCES}

[1] Bai, Y., Wu, J., Clark, C. M., Naeem, S., Pan, Q., Huang, J., Zhang, L., Han, X. (2010): Tradeoffs and thresholds in the effects of nitrogen addition on biodiversity and ecosystem functioning: evidence from Inner Mongolia Grasslands. - Global Change Biology 16(1): 358-372.

[2] Bai, Y. T., Wei, Z. J., Dai, J. Z., Yan, R. R., Liu, W. T., Wang, T. L. (2017): Responses of Plant and Soil C: N: P Stoichiometry to Fertilization in Leymus chinensis Mowing Meadow (In Chinese, with English abstract). - Ecology and Environmental Sciences 26(4): 620-627.

[3] Blaxter, K. L., Wainman, F. W., Dewey, P. J. S., Davidson, J., Denerley, H., Gunn, J. B. (2009): The effects of nitrogenous fertilizer on the nutritive value of artificially dried grass. - The Journal of Agricultural Science 76(2): 307-319.

[4] Bobbink, R., Willems, J. H. (1993): Restoration management of abandoned chalk grassland in the Netherlands. - Biodiversity and Conservation 2: 616-626.

[5] Brooks, M. L. (2010): Effects of increased soil nitrogen on the dominance of alien annual plants in the Mojave Desert. - Journal of Applied Ecology 40(2): 344-353.

[6] Bu, R. T. Y., Jiang, H. M. (2014): Comparative analysis of three different IV Analyzing methods. - Environment and Development 26(6): 64-67 (in Chinese, with English abstract).

[7] Clark, M. C., Morefield, E. P., Gilliam, S. F., Pardo, H. L. (2013): Estimated losses of plant biodiversity in the United States from historical N deposition (1985-2010). Ecology 94(7): 1441-1448.

[8] Eek, L., Zobel, K. (2001): Structure and diversity of a species-rich grassland community treated with additional illumination, fertilization and mowing. - Ecography 24(2): 157164.

[9] Gough, L., Osenberg, C. W., Gross, K. L., Collins, S. L. (2000): Fertilization effects on species density and primary productivity in herbaceous plant communities. - OIKOS 89(3): 428-439.

[10] Han, X., Tsunekawa, A., Tsubo, M., Li, S. (2011): Aboveground biomass response to increasing nitrogen deposition on grassland on the northern Loess Plateau of China. Acta Agriculturae Scandinavica, Section B - Plant Soil Science 61(2): 112-121.

[11] Hautier, Y., Seabloom, E. W., Borer, E. T., Adler, P. B., Harpole, W. S., Hillebrand, H., Lind, E. M., MacDougall, A. S., Stevens, C. J., Bakker, J. D., Buckley, Y. M., Chu, C., Collins, S. L., Daleo, P., Damschen, E. I., Davies, K. F., Fay, P. A., Firn, J., Gruner, D. S., Jin, V. L., Klein, J. A., Knops, J. M., La Pierre, K. J., Li, W., McCulley, R. L., Melbourne, B. A., Moore, J. L., O’Halloran, L. R., Prober, S. M., Risch, A. C., Sankaran, M., Schuetz, M., Hector, A. (2014): Eutrophication weakens stabilizing effects of diversity in natural grasslands. - Nature 508(7497): 521-525.

[12] Hector, A., Schmid, B., Beierkuhnlein, C., Caldeira, M. C., Diemer, M., Dimitrakopoulos, P. G., Finn, J. A., Freitas, H. (1999): Plant diversity and productivity experiments in European grasslands. - Science 286: 1123-1127.

[13] Hejcman, M., Klaudisová, M., Schellberg, J., Honsová, D. (2007): The Rengen Grassland Experiment: plant species composition after 64 years of fertilizer application. Agriculture, Ecosystems \& Environment 122(2): 259-266.

[14] Houlton, B. Z., Wang, Y. P., Vitousek, P. M., Field, C. B. (2008): A unifying framework for dinitrogen fixation in the terrestrial biosphere. - Nature 454(7202): 327-330.

[15] Huberty, L. E., Gross, K. L., Miller, C. J. (1998): Effects of nitrogen addition on successional dynamics and species diversity in Michigan old-fields. - Journal of Ecology 86(5),794-803.

[16] Jiang, J., Zong, N., Song, M., Shi, P., Ma, W., Fu, G., Shen, Z., Zhang, X., Ouyang, H. (2013): Responses of ecosystem respiration and its components to fertilization in an alpine meadow on the Tibetan Plateau. - European Journal of Soil Biology 56: 101-106. 
[17] Kahmen, S., Poschlod, P., Schreiber, K. F. (2002): Conservation management of calcareous grasslands. Changes in plant species composition and response of functional traits during 25 years. - Biological Conservation 104(3): 319-328.

[18] Leimer, S., Oelmann, Y., Wirth, C., Wilcke, W. (2015): Time matters for plant diversity effects on nitrate leaching from temperate grassland. - Agriculture, Ecosystems \& Environment 211: 155-163.

[19] Li, L. J., Zeng, D. H., Yu, Z. Y., Fan, Z. P., Mao, R. (2010): Soil microbial properties under $\mathrm{N}$ and $\mathrm{P}$ additions in semi-arid, sandy grassland. - Biology and Fertility of Soils 46: 653-658.

[20] Montgomery, D. C., Mastrangelo, C. M. (1991): Some statistical process control methods for auto correlated data. - Journal of Quality Technology 23(3): 179-193.

[21] Moog, D., Poschlod, P., Kahmen, S., Schreiber, K. F. (2002): Comparison of species composition between different grassland management treatments after 25 years. Applied Vegetation Science 5(1): 99-106.

[22] Nie, S. W., Huang, S. M., Zhang, S. Q., Guo, D. D., Zhang, Q. P., Zhang, Y. T. (2012): Effects of long-term located fertilization on soils: a review. - Soils 44(2): 188-196 (in Chinese, with English abstract).

[23] Oomes, M. J. M. (1990): Changes in dry matter and nutrient yields during the restoration of species-rich grasslands. - Journal of Vegetation Science 1(3): 333-338.

[24] Pan, Y., Cassman, N., de Hollander, M., Mendes, L. W., Korevaar, H., Geerts, R. H., van Veen, J. A., Kuramae, E. E. (2014): Impact of long-term N, P, K, and NPK fertilization on the composition and potential functions of the bacterial community in grassland soil. FEMS Microbiol Ecol 90(1): 195-205.

[25] Pegtel, D. M., Bakker, J. P., Verweij, J. L., Fresco, L. E. (1996): N, K and P deficiency in chronosequential cut summer-dry grasslands on gley podzol after the cessation of fertilizer application. - Plant and Soil 178: 121-131.

[26] Pielou, E. C. (1966): The measurement of diversity in different types of biological collections. - Journal of Theoretical Biology 13: 131-144.

[27] Plassmann, K., Edwards-Jones, G., Jones, M. L. (2009): The effects of low levels of nitrogen deposition and grazing on dune grassland. - Sci Total Environ 407(4): 13911404.

[28] Rajaniemi, T. K. (2002): Why does fertilization reduce plant species diversity? Testing three competition-based hypotheses. - Journal of Ecology 90(2): 316-324.

[29] Richardson, C. J., Ferrell, G. M., Vaithiyanathan, P. (1999): Nutrient effects on stand structure, resorption efficiency, and secondary compounds in everglades sawgrass. Ecology 80(7): 2182-2192.

[30] Sala, O. E., Biondini, M. E., Lauenroth, W. K. (1988): Bias in estimates of primary production: an analytical solution. - Ecological Modelling 44(2): 43-55.

[31] Shannon, C. E., Weaver, W. (1949): The Mathematical Theory of Communication. University of Illinois Press, Urbana, IL.

[32] Su, J., Li, X., Li, X., Feng, L. (2012): Effects of additional N on herbaceous species of desertified steppe in arid regions of China: a four-year field study. - Ecological Research 28(1): 21-28.

[33] Vitousek, P. M. (2015): Grassland ecology: complexity of nutrient constraints. - Nat Plants (1): 1-2.

[34] Wamelinka, G. W. W., Wieggersa, H. J. J., Reindsa, G. J., Krosa, J., MolDijkstraa, J. P., Oijenb, M. (2009): Modelling impacts of changes in carbon dioxide concentration, climate and nitrogen deposition on carbon sequestration by European forests and forest soils. - Forest Ecology and Management. 258(8): 1794-1805.

[35] Warman, P. R., Cooper, J. M. (2000): Fertilization of a mixed forage crop with fresh and composted chicken manure and NPK fertilizer: effects on soil and tissue $\mathrm{Ca}, \mathrm{Mg}, \mathrm{S}, \mathrm{B}$, $\mathrm{Cu}, \mathrm{Fe}, \mathrm{Mn}$ and Zn. - Canadian Journal of Soil Science 80(2): 345-352. 
[36] Xu, B., Gao, Z., Wang, J., Xu, W., Palta, J. A., Chen, Y. (2015): N: P ratio of the grass Bothriochloa ischaemum mixed with the legume Lespedeza davurica under varying water and fertilizer supplies. - Plant and Soil 400(1-2): 67-79.

[37] Yahdjian, L., Gherardi, L., Sala, O. E. (2011): Nitrogen limitation in arid-subhumid ecosystems: a meta-analysis of fertilization studies. - Journal of Arid Environments 75(8): 675-680.

[38] Yu, L., Song, X. L., Zhao, J. N., Wang, H., Bai, L., Yang, D. L. (2015): Responses of plant diversity and primary productivity to nutrient addition in a Stipa baicalensis grassland, China. - Journal of Integrative Agriculture 10(14): 2099-2108.

[39] Zeng, D. H., Li, L. J., Fahey, T. J., Yu, Z. Y., Fan, Z. P., Chen, F. S. (2009): Effects of nitrogen addition on vegetation and ecosystem carbon in a semi-arid grassland. Biogeochemistry 98(1-3): 185-193.

[40] Zhang, R., Wang, Z., Han, G., Schellenberg, M. P., Wu, Q., Gu, C. (2018): Grazing induced changes in plant diversity is a critical factor controlling grassland productivity in the Desert Steppe, Northern China. - Agriculture, Ecosystems \& Environment 265: 7383.

[41] Zhou, X., Bowker, M. A., Tao, Y., Wu, L., Zhang, Y. (2018): Chronic nitrogen addition induces a cascade of plant community responses with both seasonal and progressive dynamics. - Sci Total Environ 626: 99-108. 